\title{
THE DEVELOPMENT OF MUSLIM NATION IN BOSNIA AND HERZEGOVINA
}

\author{
Danuta GIBAS-KRZAK
}

The main goal of this article is to show the conditions and circumstances of the formation of Muslim nation in communist Yugoslavia and the increase of its significance during and after the civil war 1992-1995. Furthermore, author presents the characteristics of contemporary nationalism, and distinguishes specific Balkan nationalism, which is often chauvinistic, ahistorical, militant and exclusive, of ethnocultural character. The identity of Bosnian Muslims originated from belief that their origin, language and culture related to Bosnia and Herzegovina, which makes them different from the Turks and other Islamic nations living in the Ottoman Empire. The genesis of forming Muslim nation in Yugoslavia is interpreted in various ways by the researchers. There is a hypothesis that it has been developed thanks to activity of young people who convinced Josip Broz Tito that such decision would reduce tensions between the Serbs and Croats in Bosnia and Herzegovina. According to the Author, Muslim inhabitants of Bosnia and Herzegovina can't be a separate nation, above all, since the followers of Islam were nationally indifferent, and their cultural legacy is completely different than Serbian and Croatian legacy.

Keywords: Yugoslavia, Bosnia and Herzegovina, Balkans, nationalism, nation, ethnic conflicts, Muslims.

\section{Introduction}

Nationalism should be understood as a political view, according to which natural communities living within one political system, should be independent of the others and have the same rights as the countries having similar position in global order. Therefore, nationalism is a trend that opposes inter-

\footnotetext{
Danuta Gibas-Krzak, Ph. D., Warsaw, Poland
} 
national movements and focuses on localness in almost the same way as in the period of tribal communities ${ }^{1}$. The definitions of nationalism fluctuate around claims that racial, cultural, historical ties are usually connected with nationality, although they suit ethnicity more. Such definitions of nationalism are often deliberately used by the politicians and governments who use nationalist ideologies for their particularistic goals. The doctrine of nationalism can't be clearly defined, but in the 19th century, theories dividing nationalism into Western and Eastern has become widespread. Western nationalism has unification features and is connected with the ideas of liberalism, whereas, Eastern nationalism aims at creation of new cultures competing with the existing ones. ${ }^{2}$ Eastern nationalism is defined as "fanatical". The society infected by it is stuck in complicated systems of territorial, ancestral, religious connections. It has also tendency to similarities between the state and culture, which is the essence of this nationalism. ${ }^{3}$ In the 20th century, the term nationalism has gained its current meaning. It includes thematic scope related to the process of forming or developing nations, national sentiment or being aware of belonging to a nation; language and symbolism of nation; social and political movement; doctrine or ideology of nation ${ }^{4}$. The ideology of nationalism is defined in various ways, most of the definitions are similar, therefore, we can distinguish its common features. The main question is overriding interest in the nation; therefore, nationalism is the idea that places nation in the centre of interest. Nationalism understood in this way is an ideological movement that wants to gain and maintain autonomy, unity and identity of society, of which members are regarded as a real or potential nation ${ }^{5}$. Modern nationalism has two significant features: timelessness and universality that are connected with historical rooting and huge dynamics because it is constantly more or less transformed, depending on external and internal factors. The danger lies in that that European nationalism has usually negative connotations. It is associated with the growth of tensions and ethnic conflicts directly threatening the peace in Europe $e^{6}$. These conflicts are additionally strengthened by religious differences. In many cases, nationalism is equated with chauvinism and means unquestioning manifestation of sense of superiority in all fields of life towards other

\footnotetext{
1 David Robertson, Stownik polityki (Warsaw, 2009) [Originally published in English under the title The Routledge Dictionary of Politics], pp. 250-251.

2 Sebastian Wojciechowski, Nacjonalizm w Europie Środkowo-Wschodniej [Nationalism in Central and Eastern Europe] (Wrocław, 1999), p. 30.

3 Ibidem.

4 Anthony D. Smith, Nacjonalizm (Warsaw, 2007) [Originally published in English under the title Nationalism: Theory, Ideology, History], pp.16-17.

5 Ibidem, p. 21

6 S. Wojciechowski, Nacjonalizm w Europie Środkowo-Wschodniej, pp.30-31.
} 
nations, a belief in exclusive rightness of the own nation, when other nations are treated with contempt or hatred.

In the classic Encyclopedists' perspective, nation is a group of people living in a given territory, having the same law and government. Modern understanding of the notion of nation generally derives from two Jean Jacques Rousseau's interpretations who treated nation as a "political community" and from Johann Gotfried Herder who emphasized the importance of "cultural community", which has led to creation of definition of cultural nation. ${ }^{7}$ Moreover, two concepts of nation have become widespread: territorial and ethnic. The basis for definition of the first type of nation is a sense of community, being an effect of interactions occurring in the specific territory, in clearly defined geographical borders. In this case, nation should be understood as a political community-inevitably limited and sovereign. It should be emphasized that ethnical understanding of transition from nation to the state occurs above all in Eastern Europe and the Balkans. ${ }^{8}$ Within this approach, we can say about transforming ethnic ties and sentiments into national ones during the processes of mobilization, territorialisation and politicization. This theory puts emphasis on such elements as: genealogy, folk populism, customs, dialects and nativeness. Moreover, ties of origin and myths related to it acquire significance. In such understanding of the nation, civil codes and institutions that hold territorial nations together are replaced with customs and dialects.

\section{The identity of Balkan nationalisms}

In the Balkans, the phenomenon of the so-called ethnic borderland occurs, where national consciousness is only being crystallized. Balkan nationalism is often chauvinistic, ahistorical, militant and exclusive, of ethnocultural character. The nations in this part of Europe are treated as cultural nations, whereas, religious factor is an important factor of internal mobilization. It results from complicated history of this region because, during Turkish occupation, the inhabitants were supported mainly by the churches. Until the 19th century, religious institutions were the only defenders of ethnic and cultural identity. ${ }^{9}$ During the Balkan wars (1912-1913), the name Balkans has become

\footnotetext{
$7 \quad$ Friedrich Meinecke, Weltbürgertum und Nationalstaat: Studien zur Genesis des deutschen Nationalstaates [World Bourgeoisie and Nation State: Studies on the Genesis of the German Nation State] (Munich-Berlin, 1928), pp. 3-5.

8 Anthony D. Smith, Etniczne źródła narodów [Originally published in English under the title The Ethnic Origins of Nations] (Kraków, 2009), p. 200.

9 Urs Altermatt, Sarajewo przestrzega: Etnonacjonalizm w Europie (Kraków 1998) [Originally published in German under the title Das Fanal von Sarajevo: Ethnonationalismus in Europa (The Warning of Sarajevo: Ethnonationalism in Europe], p. 159.
} 
widespread in a political sense and stigmatizing term "Balkan powder keg" has emerged, which means clash of conflicting interests, as well as confusion and chaos. It is also a metaphorical reflection of various ethnic conflicts, cultural and religious disputes, dangerous turmoil and entering into dangerous political, ideological and ethnic reactions ${ }^{10}$. For better explanation of specificity of the region, other negative terms connected with the Balkans have been developed, for example, "Balkan powder keg", which defines brittle character of events, imposing the thinking of this region as a place of unpredictable events, whose inhabitants are unpredictable. The term "Balkanization" that has become widespread since the Berlin Congress means nationalist fragmentation, which is also a synonym of tense relations between small neighbouring countries leading to never-ending conflicts. ${ }^{11}$ Nationalisms in the Balkans is particularly dangerous due to the fact specific type of Eastern nationalism, also called "hot" has developed there. It is characterized both as "venomous" and "fanatical". It refers to complicated territorial, ancestral, cultural and religious relations, and its goal is to create new cultures that compete with the ones that already existed. Destructive character of such nationalism manifests usually in spectacular actions taken in order to defend national interest that leads to reactivation of already existing antagonism..$^{12}$ In the eyes of people in the West, the Balkans are perceived as a region dominated by irrational nationalism, which due to the lack of higher cultures, appeals to folk output. ${ }^{13}$ The nationalists representing this concept refer to customary and language ties. In modern ethnic conflicts in the Balkans, the opponents want to dominate, subdue and destroy and even annihilate the other side. Such nationalism may lead to revival of atavistic cult of own blood and own territory. ${ }^{14}$ Therefore, these conflicts are determined and permanent in their goals. It seems that, from historical perspective, they will never end. Nationalism in the $21^{\text {st }}$ century has become one of the major problems affecting international security because after the end of the cold war, the division into powerful and satisfied, powerful and dissatisfied, weak and satisfied, weak and dissatisfied countries and nations has returned. The last group, having potentially the most short-tempered

\footnotetext{
10 Tomasz Wituch, "Bałkany - szkic definicji” ["Balkans - definition sketch"], Dzieje Najnowsze XXX (1998), No. 2: 139.

11 Magdalena Koch, “'My’ i ‘Oni', 'Swój, i ‘Obcy’: Bałkany XX wieku z perspektywy kolonialnej" ['We' and 'They', 'His', and 'Alien': Balkans of the 20th Century from a Colonial Perspective'], Porównania 6 (2009), No. 6: 79.

12 S. Wojciechowski, Nacjonalizm w Europie Środkowo-Wschodniej, p. 41.

13 Krzysztof Jaskułowski, Nacjonalizm bez narodów: Nacjonalizm w koncepcjach anglosaskich nauk społecznych [Nationalism Without Nations: Nationalism in the Concepts of Anglo-Saxon Social Sciences] (Wrocław, 2009), p. 206.

14 Adam Koseski, "Bałkańskie konflikty etniczne w latach dziewięćdziesiątych XX wieku” ["Balkan ethnic conflicts in the 1990s"], Rocznik Nauk Politycznych (2000), No. 1 (2): 82.
} 
character occurs mainly in post-Soviet area, in East-Central Europe, Balkan Peninsula and Middle East. ${ }^{15}$

\section{Muslim nation in the Balkans}

At the stage of forming a nation, there were two opposing tendencies in Bosnia and Herzegovina: integrative and diversifying. The first one refers to nation as a state community, and the second one to cultural community with significant religious factor, which was interpreted as ethnic and assumed building the nations around faith. ${ }^{16}$ Whereas, religion in the culture of this community was treated as superior to language, literature, art and customs. The dispute over Bosnia and Herzegovina was a part of general rivalry for the position of a leader between South Slavs, in which two ideas were competing: Greater Serbia and Greater Croatia. In Bosnian historiography, there is a constant discussion on thousand-year-old tradition and continuity of history of Bosnia and Herzegovina, including also the possibility of forming a nation. It is often defined as a continuation from the medieval ruler, Ban Kulin, through Bogomils, accepting Islam to modern times. ${ }^{17}$ The nationality of the followers of Islam, understood as clearly defined regional identity entity, which included both medieval kingdom and separate wilayah in the Ottoman Empire, was becoming an important element in ethnic landscape of this area. Serbian and Croatian historiographic reception stands in opposition to it because Bosnia and Herzegovina is not treated as a separate entity, but as a central part of national space of the Serbs or Croats. It seems that discussion on this subject has come to a standstill because research in Bosnia and Herzegovina concerning the genesis of nation are in deep crisis. There isn't neither developed model, nor methodology. ${ }^{18}$ Although Muslim inhabitants of Bosnia and Herzegovina, who should be treated as Turkish Slavs, played more and more important role on this territory, it was communist Yugoslavia that helped to shape special type of Muslim nation, now called Bosniak.

Muslim population was appreciated by the Communist Party during the first meeting of Ant-Fascist Council for the National Liberation of Yugoslavia in November 1942, when Josip Broz-Tito emphasized that Yugoslavia is

15 T. Wituch, "Bałkany - szkic definicji": 139.

16 Danuta Gibas-Krzak, Bośnia i Hercegowina: determinanty dziejów: Pomiędzy Serbami, Chorwatami a supremacja Muzulmanów [Bosnia and Herzegovina: Determinants of History: Between Serbs, Croats and Muslim Supremacy] (Częstochowa, 2016), p. 150.

17 Husnija Kamberović, Historiografia u Bosni i Hercegovini u službi politike [Historiography in Bosnia and Herzegovina in the Service of Politics] (Zagreb, 2012), pp.140-141.

18 Ibidem, p.142. 
inhabited by the nations having equal rights: Serbs, Croatians, Slovenians, Montenegrins, Macedonians and Muslims. ${ }^{19}$ In the next years, Muslim population actively participated in creation of ethnic policy, being in the opposition to Croatian and Serbian concept. According to many Bosniak authors, their stand expressed negation of Greater Croatian annexation of Bosnia and Herzegovina within Independent State of Croatia, as well as the plan of Greater Serbian inclusion of Bosnia and Herzegovina, which was supposed to be the part of homogeneous Greater Serbia. ${ }^{20}$ At the end of 1950s a campaign promoting Yugoslavian nationality had weakened, mainly because society feared centralization of power and Serbian control. The party's policy on national issue was dominated by more liberal approach, which resulted in formal recognition of the Muslims in ethic sense. In November 1959, Josip Broz-Tito, during the 2nd Plenum of the Central Committee of the League of Communists of Yugoslavia emphasized the freedom of choice for every inhabitant. ${ }^{21}$ Census from 1961 did not grant the followers of Islam national rights, but introduced the category of "Muslim in ethnic sense". Such status was chosen by 972954 people, including 842954 inhabitants of Bosnia and Herzegovina ${ }^{22}$. When Aleksander Ranković, vice-president of Yugoslavia and the head of security service regarded as the enemy of Kosovar Albanians who was also sceptical about granting Muslim population the status of nation, had left political scene, new generation of politicians seized power in Bosnia and Herzegovina and $t$ initiated dynamic debate on Muslim nation. ${ }^{23}$ In 1967 Muhamed Filipović published and essay on Bosnian spirit in literature (Bosanski duh u književnosti - šta je to? [Bosnian Spirit in Literature - What is It?]), which was regarded by some communists as a manifesto of anti-government activity and example of Muslim nationalism. In the same year, a team of experts from the faculty of political sciences in Sarajevo was appointed. This team was led by Hamdija Čemerlić who worked on the project called The position of the Muslims in Bosnia and Herzegovina on national identification (Stav muslimana Bosne i Hercegovine u pogledu nacionalnog opredjeljenja). The researchers collected arguments for

\footnotetext{
19 In this case, small letter is used because followers of Islam were not treated then as a nation.

20 Robert J. Donia, John V. A. Fine, Jr., Bosna i Hercegovina: iznevjerena tradicija (Sarajevo, 2011) [Originally published in English under the title Bosnia and Hercegovina: A Tradition Betrayed], p. 160.

21 Izet Šabotić, "Nacionalno pitanje Bošnjaka - Muslimana u projekcijama Komunističke Partije/ Saveza Komunista Jugoslavije" ["The National Question of Bosniaks - Muslims in the Projections of the Communist Party / League of Communists of Yugoslavia"], in: Identitet Bosne i Hercegovine kroz historiju: Zbornik Radova, Husnija Kamberović (ed.), volume 2 (Sarajevo, 2011), p. 141.

22 Ibidem, p. 142.

23 Dženita Sarač-Rujanac, Odnos vjerskog i nacionalnog u identitetu Bošnjaka od 1980. do 1990. godine [The Relation of Religious and National in the Identity of Bosniaks from 1980 to 1990] (Sarajevo, 2012), p. 43.
} 
Muslim nationality in a way that could be approved by party leaders, whereas, one of the authors of the project, Atif Purivatra, proposed a thesis of ethnic and national uniqueness of the followers of Islam. ${ }^{24}$ The identity of Bosnian Muslims originated from belief that their origin, language and culture were connected with Bosnia and Herzegovina, which makes them different from the Turks and other Islamic nations living in the empire under the rule of Padishahs. A hypothesis about gradual building of unique Muslim community in Bosnia and Herzegovina under the rule of the Ottomans has been developed. ${ }^{25}$ Two sessions of the Central Committee of the League of Communists of Bosnia and Herzegovina, in January and May 1968 were decisive for recognition of Muslim nation in Yugoslavia. The issue of increasing economic and political importance of the Republic was raised again and the status of the so-called Bošnjak was discussed, concluding that Muslim nation exists, and it is a unique cultural and historical community. As a result of many propaganda actions, the League of Communists admitted that the Muslims should be treated as a separate nation, whereas, during census in 1971, the inhabitants of Bosnia and Herzegovina would identify as Muslims - in national sense. 1482 400 inhabitants (39,6\%) identified themselves as Muslims, 1393100 people, that is, $37,2 \%$, identified as the Serbs and Croatian nationality was chosen by 772500 , that is, $20,6 \%$, whereas, status of Yugoslavian nation was chosen only by 43800 inhabitants, that is, $1,2 \%{ }^{26}$.

The genesis of forming Muslim nation in Yugoslavia is interpreted in various ways by the researchers. There is a hypothesis that it has been developed thanks to activity of young people who convinced Josip Broz-Tito that such decision would reduce tensions between the Serbs and Croatians in Bosnia and Herzegovina, whereas, Bosnia and Herzegovina was supposed to be a tampon $z o n e$, dividing areas with the strongest separatisms and nationalisms. ${ }^{27}$ There were also dilemmas that were revealed in subsequent years, not only in scientific discourse, but above all journalistic. The Muslims were treated in Serbian media as a nationality, whereas, Sarajevo publications were saying that the Muslims is a nation in a historical sense, just like Croatians or Serbs, and it

\footnotetext{
24 Enver Redžić, Sto godina muslimanske politike: U tezama i kontraverzama istorijske nauke: Geneza ideje bosanske, bošnjačke nacije [One Hundred Years of Muslim Politics: In The Theses and Controversies of Historical Science: The Genesis of the Idea of the Bosnian, Bosniak Nation] (Sarajevo, 2000), pp. 79-80.

25 H. Kamberović, Historiografia u Bosni i Hercegovini u službi politike, p. 25.

26 Piotr Eberhardt, Przemiany demograficzno-etniczne na obszarze Jugosławii w XX wieku [Demographic and Ethnic Changes in Yugoslavia in the 20th Century] (Lublin, 2005), p. 77.

27 Miša Gleni [Misha Glenny], Pad Jugoslavije: Treći balkanski rat (Belgrade, 2002) [Originally published in English under the title The Fall of Yugoslavia: The Third Balkan War], pp.149-150.
} 
would be a mistake to claim that it was an "artificial creation". ${ }^{28}$ Nevertheless, discussion on this subject is being continued to this day, also in neighbouring countries, Croatia and Serbia, having often political character and stimulating "ethnic upheaval" in Bosnia and Herzegovina.

\section{The development of Muslim nationalism}

In the 1970s and 1980s, many successful attempts were made to strengthen Muslim-Bosniak nation on the forum of federation. In 1971, Pašaga Mandžić and the so-called Tuzla Group were accused of "developing Muslim nationalism and chauvinism". They were sentenced for criticizing decisions of partisan command during the World War II, which in their opinion, led to excessive losses in Muslim population in eastern Bosnia. ${ }^{29}$ In 1974, during discussion on ethnic development of Bosnia and Herzegovina, Branislav Đurđev said that the process of forming Muslim nation did not consist only of Islamization, but also gradual social identity under conditions of the Ottoman power. In the 1970s, Yugoslav authorities warned that the goal of Islamic fundamentalists is Islamization of Bosnia and Herzegovina. The authorities strived to separate religious from national elements, in order to prevent "secular" Islam from being a threat, and above all competition for Yugoslavian nationality. They were afraid that Yugoslavia would become the next stage of Islamization of Europe and bridge to propagate Muslim fundamentalism in Western Europe $^{30}$. In 1983, thirteen members of the organization called "Young Muslims", among others, Alija Izetbegović, Husein Živalj, Hasan Čengić, Omer Behmen and Džemaludin Latić were accused of: pan-Islamism, anti-communism, terrorism, connections with the world of Islam and Iranian revolution, as well as calling to ethnically pure Bosnia and Herzegovina. The importance of "Islamic Declaration" was emphasized during the process. This declaration was signed thirteen years earlier by Izetbegovic and it was regarded as an ideological program of Muslim nationalism, because one of its goals was establishment of Muslim order in Bosnia and Herzegovina, even with the use of force. ${ }^{31}$ The judges found them guilty and sentenced to between 6 months and 15 years

\footnotetext{
28 I. Šabotić, "Nacionalno pitanje Bošnjaka - Muslimana u projekcijama Komunističke Partije/ Saveza Komunista Jugoslavije", pp. 147-148.

29 Šaćir Filandra, Bošnjačka politika u XX. stoljeću [Bosniak Politics in the 20th Century] (Sarajevo, 1998), pp. 248-250.

30 Darko Trifunović, Islamic Terrorism and Al Qaeda in the Balkans: Testimony of Former Al Qaeda Lieutenant (Alexandria, 2014), p. 29.

31 Ljubomir Borovčanin, Bosanske ratne simulacije: Uzroci, karakteristike i posljedice rata u Bosni $i$ Hercegovini 1992-1995 [Bosnian War Simulations: Causes, Characteristics and Consequences of the War in Bosnia and Herzegovina 1992-1995] (Belgrade, 2001), p. 42.
} 
of prison. In the justification of the sentence, it was said that the accused belonged to a group of nationalists supporting ethnically pure Bosnia that was supposed to be a republic organized in accordance with the Sharia law and a part of large Islamic state, stretching from Afghanistan to South-East Europe. ${ }^{32}$ At the end of the 1980 s, the convicts were released early from prison and then they became political dissidents in the society undergoing transformation towards pluralism. In this way, using their good situation, they were able to gain power, build foundations of new Bosnian state that has been established after the civil war.

In 1990, another debate on Muslim identity took place, which was inspired by the publication of Alija Isakovićs a study which consisted of articles about the process of building Muslim nation between the end of the 19th century and the close of the $20^{\text {th }}$ century. In 1991, other well-known intellectuals: Atif Purivara, Mustafa Imamović and Rusmir Mahmutćejahić supported Muslim nationality, and rejected of idea Bosniak nationality. ${ }^{33}$ The legitimization of Muslim nation met with strong opposition, especially in Serbia, where writer Dobrica Ćosić and historian Jovan Marjanović claimed that communist leaders artificially construct nations and such experiment would have negative consequences. The communists from Macedonia have not supported the granting national status to the Muslims, because they were afraid that Muslim minority in their republic would demand emancipation and then separate from recently recognized (in 1945) Macedonian nation.

The creation of Muslim nation has not only become the factor antagonizing nationalities and ethnic groups, but also decreased the number of people who identified themselves as Yugoslavians in comparison with previous census. The legitimization of the followers of Islam in some sense ruined the chances to implement the idea of Yugoslavian nation, which was supposed to unite the inhabitants. However, the Muslims have never been a straight majority in Bosnia and Herzegovina, although its population, above all, due to high birth rate, has considerably increased, whereas, population of the Serbs has decreased by $4,8 \%$ and Croatians by $2,4 \%{ }^{34}$. It should be added that Islam professed by the inhabitants of the Republic was not radical. The majority of Muslims were Sunnis, although Sufism played a significant role as a theological and intellectual trend, often called Muslim mysticism. Faith was of superficial character and visits at the mosques were limited mainly to rare visits

\footnotetext{
32 D. Trifunović, Islamic Terrorism and Al Qaeda in the Balkans, p.26.

33 Rusmir Mahmutćehajić, "Bošnjaci i/ili/ Muslimani" ["Bosniaks and/or/ Muslims"], in: Atif Purivatra, Mustafa Imamović, Rusmir Mahmutćehajić, Muslimani i bošnjaštvo (Sarajevo, 1991), pp. 77-78.

34 P. Eberhardt, Przemiany demograficzno-etniczne na obszarze Jugosławii w XX wieku, pp. 77-78.
} 
connected with the most significant events such as: birth, marriage or funeral. $10 \%$ of the Bosnians identified themselves as atheists or agnostics. ${ }^{35}$ Another element of the revival of life of this community was development of mystical currents of Islam, among others, Dervish Movement. Many articles published in the "Preporod", in which importance of religion as a nation-building factor was emphasized, indicating also the necessity of close connection of religious with national identity, made people afraid of development of Muslim fundamentalism. ${ }^{36}$ In the 1980 s, madrasa teachers were tried for distributing illegal literature propagating militant Islam and Muslim nationalism. Muslims soon demanded more rights. There were more and more demands that concerned not only increasing the number of new sacred and prayer places, but also improving the functioning of Islamic institutions. Young people were particularly active. The travels to Islamic countries made them inspired for another demands, including demands of political character. ${ }^{37}$ The members of Muslim National Committee for Bosnia and Herzegovina demanded disbandment of security service SDB (Služba državne bezbjednosti) and the creation of a new constitution, in which Muslims were supposed to be the only constitutive nation, whereas, other nations would only have cultural autonomy. ${ }^{38}$ Demographic development of the followers of Islam increased their population in 1991 to 1905800 , making them majority due to the fact that Muslims constituted 43,7\% inhabitants of Bosnia and Herzegovina. ${ }^{39}$ Similar scenario was conducted to those in Kosovo, where Muslims had dominated and driven out Christian population, gaining numerical superiority over them, which resulted in demands of secession and then sovereignty. Bosnian nationalism reached its apogee during the civil war that has resulted in the demise of communist Yugoslavia, when the change of ethnonym from "Muslim" to "Bosniak" (Bošnjak) in September 1993 during Bosniak Congress in Sarajevo strengthened the position of Muslim nation. The delegates of Muslim minority from Serbia and Montenegro participated in this congress. ${ }^{40}$

\footnotetext{
35 Fuad Saltaga, Muslimanska nacija u Jugoslaviji [Muslim Nation in Yugoslavia] (Sarajevo, 1991), pp. 218-219.

36 Omer Behmen, Na dnu dna [At the Bottom] (Sarajevo, 2006), pp. 214-215.

37 Džon R. Šindler [John R. Schindler], Nesveti terror: Bosna, Al Kaida i uspon globalnog dżihada (Belgrade, 2009) [Originally published in English under the title Unholy Terror: Bosnia, Al-Qa'ida, and the Rise of Global Jihad], pp.41-42.

38 D. Gibas-Krzak, Bośnia i Hercegowina: determinanty dziejów: Pomiędzy Serbami, Chorwatami a supremacją Muzulmanów, p.160.

39 P. Eberhardt, Przemiany demograficzno-etniczne na obszarze Jugostawii w XX wieku, p. 79.

40 Krzysztof M. Zalewski, Naród, religia, rasa. Muzulmańskie ideologie i ruchy narodowe pogranicza w Południowo-Wschodniej Europie: Przykład Sandżaka nowopazarskiego w XX wieku [Nation, Religion, Race: Muslim Ideologies and National Movements of the Borderland in Southeastern Europe: An example of the Sanjak of Novi Pazar in the 20th Century] (Warsaw, 2010), p.195.
} 
Through decisions made in Dayton in 1995, international community wanted to enable nations living in Bosnia and Herzegovina to create multinational and multicultural state and legal and administrative foundations. However, unstable country has been established that comprises of two parts called entities: Serbian Republic (Republika Srpska in Serbian) and Croatian-Muslim Federation of Bosnia and Herzegovina. Every entity has its own constitution, government, police and armed forces. Since the constitution clearly states that there are three constitutional nations, at the central centre, there is collegial 3-person presidency - Presidium of Bosnia and Herzegovina comprising of the members of three ethnic communities: Muslims, Croatians and Serbs. However, constitutional order developed by American lawyers has caused that political system of this state has dysfunctional features, which makes ruling it and building civil society more difficult. Every territorial unit has separate executive and legislative authority, which generates large, expensive civil service. Such institutional order allows politicians to blame one another for the problems and use ethnic questions to stay in power. The way both chambers of parliament are functioning is determined by ethnic divisions because vital interests of every of three constitutional nations must be preserved. Part of the problems related to the functioning of political system result from the fact that Bosnia and Herzegovina is in fact an international protectorate.$^{41}$ An important aspect of ethnic changes that have occurred after the civil war is strengthening national identity of Muslims, who now identify themselves as Bosniaks. The change of ethnonym was supposed to be an essential element in the process of abreacting of this community after the civil war. Before the war, many followers of Islam did not think that they belong to Muslim nation because religious questions were everyone's personal choice, whereas, after the war, being a Muslim (Bosniak) in sense national has become a faith, even for atheists. Such actions were aimed at recovering from traumatic wartime experiences because opinion-forming environments in Western Europe and United States think it was the followers of Islam who were the main victims of the civil war. ${ }^{42}$ However, such argumentation is false because not only Muslims suffered physical and psychical losses, and explanation that the nation has formed while healing post-traumatic trauma is not convincing. It gives rise to other divisions in the society, in which Bosniaks (Muslims) have become de-

\footnotetext{
41 Krzysztof Krysieniel, W cieniu Dayton: Bośnia i Hercegowina między etnokracją i demokracja konsocjonalna [In the Shadow of Dayton: Bosnia and Herzegovina between Ethnocracy and Consocational Democracy] (Warsaw, 2012), p. 263.

42 Michael Ignatieff, Blood and Belonging: Journeys into the new Nationalism (Toronto, 1993), p. 33 .
} 
mographically dominant entity. ${ }^{43}$ This fact is without scruple used for promotion of Islam and development of fundamentalist sects, including Wahhabis who are financially supported by Saudi Arabia.

\section{Conclusions}

Ethnic policy of the president Josip-Broz Tito, which aimed at combating nationalisms, did not bring expected results, which can be seen in the divisions in small Yugoslavia, as Bosnia and Herzegovina was described due to its ethnic specificity. Muslim elites feared homogenization of culture, which manifested in aspirations to create Yugoslavian nationality, criticizing combating Albanian separatist movements by the communists. The conservative wing in the environment of the party leaders of the Republic, regarded as the most loyal to Tito, supported actions aimed at polarizing splitting tendencies, including Muslim nationalism, although consequences of decisions made at that time were far-reaching and rather negative when it comes to ethnic policy. They have developed a new model of nation (quasi-nation) that has started dominating in Bosnia and Herzegovina, becoming a significant factor of fragmentation of society. Creating Muslim nationality has also triggered megalomania among the followers of Islam who started attributing features of a constitutive nation to themselves. In the case of the members of Muslim community, the identity of ethnic and religious character played the key role. It was indicated that it was a result of historical continuation, from the Middle Ages to modern times. However, taking theories about nation into account, it is practically impossible to create a model of Bosnian nation (Bosniak). Nation should be characterized by common language, territory, cultural legacy, participation in national culture, common resource of thoughts and emotions, existence of separate consciousness, sense of being a nation and having common state in the past. Above all, nation is a community convinced of identical consciousness and emotional ties. ${ }^{44}$ It seems that Muslim inhabitants of Bosnia and Herzegovina who speak South Slavic language that is now called Bosnian, ${ }^{45}$ in accordance with this model, can't be a separate nation, above all,

43 Bosnia and Herzegovina has 3,849,891 inhabitants, 50,1\% of Bosniaks, 30,8\% of Serbs and $15,4 \%$ of Croats (other nationalities 2,7\%), https://www.cia.gov/library/publications/the-worldfactbook/geos/bk.html, accessed on June 20, 2019.

44 Marek Waldenberg, Kwestie narodowe w Europie Środkowo-Wschodniej: Dzieje, Idee [National Issues in Central and Eastern Europe: History, Ideas] (Warsaw, 1992), pp. 16-18.

45 Prior to the 1990s official name of the language in Bosnia and Hercegovina was called srpskohrvatski ili hrvatskosrpski (Serbo-Croatian or Croato-Serbian). During the period from 1945 to 1990 Catholic Church as the religious organization which was followed by the vast majority of Bosnian-Hercegovinian Croats continued to call in its publications their language Croatian. 
due to the fact that the followers of Islam were nationally indifferent and their cultural legacy is completely different than Serbian and Croatian legacy.

Since about 2005, "transformation crisis" has begun in Bosnia and Herzegovina because politicians of three constitutional nations don't want to build multicultural society, but strengthen feuds between nations that, although frozen, may lead to explosion in Bosnian powder $\mathrm{keg}^{46}$ The dysfunctionality of political system of this state is closely connected with complicated ethnic situation, because political system was dominated by the rule of priority of ethnic group over individual. Bosnia and Herzegovina at the turn of 20th and 21 st century has become a model example of sad specificity of borderland with conflicted multi-ethnic community. Whereas, "Bosnian borderland" accepting mutual cultural differences among inhabitants has sunk into oblivion. ${ }^{47}$ The paradigm of the so-called cultural borderland is currently becoming more influential - understood as national and civilizational borderland, where Muslim national community and the so-called Bosniak identity have been formed in opposition to Croatians and Serbs. Therefore, it is highly unlikely that three constitutional nations will build consolidated society because only international supervision in Bosnia and Herzegovina may keep "fragile peace".

\section{Bibliography:}

Altermatt, Urs. Sarajewo przestrzega: Etnonacjonalizm w Europie, Kraków, 1998 [Originally published in German under the title Das Fanal von Sarajevo: Ethnonationalismus in Europa (The Warning of Sarajevo: Ethnonationalism in Europe)]

Behmen, Omer. Na dnu dna [At the Bottom], Sarajevo, 2006.

Borovčanin, Ljubomir. Bosanske ratne simulacije: Uzroci, karakteristike i posljedice rata u Bosni i Hercegovini 1992-1995 [Bosnian War Simulations: Causes, Characteristics and Consequences of the War in Bosnia and Herzegovina 1992-1995], Belgrade, 2001.

Donia, Robert J., Fine, John V. A. Jr., Bosna i Hercegovina: iznevjerena tradicija, Sarajevo, 2011 [Originally published in English under the title Bosnia and Hercegovina: A Tradition Betrayed].

\footnotetext{
The term Bosnian language differs from recently created ethnonym Bosniak, so it is reasonable to assume that it was also adopted in order to be imposed to Croats and Serbs in Bosnia and Hercegovina, putting thus in jeopardy their right to speak their own languages.

46 Adam Koseski, "Bałkańskie konflikty etniczne na przełomie XX i XXI stulecia" ['Balkan Ethnic Conflicts at the Turn of the 20th and 21st Centuries'], in: Bałkany etnokulturowe podtoże konfliktów, W. Konarski, A. Koseski (eds.) (Pułtusk, 2006), pp. 93-120.

47 Lilla Moroz-Grzelak, "The Specificity of the Bosnia and Herzegovina Borderland and the Issue of Bosnian identity", Sprawy Narodowościowe (2007), No. 31, 2007: 313-314.
} 
Eberhardt, Piotr. Przemiany demograficzno-etniczne na obszarze Jugosławii w XX wieku [Demographic and Ethnic Changes in Yugoslavia in the 20th Century], Lublin, 2005.

Filandra, Šaćir, Bošnjačka politika u XX. stoljeću [Bosniak Politics in the 20th Century], Sarajevo, 1998.

Gibas-Krzak, Danuta. Bośnia i Hercegowina: determinanty dziejów: Pomiędzy Serbami, Chorwatami a supremacja Muzułmanów [Bosnia and Herzegovina: Determinants of History: Between Serbs, Croats and Muslim Supremacy], Częstochowa, 2016.

Gleni, Miša [Glenny, Misha]. Pad Jugoslavije: Treći balkanski rat, Belgrade, 2002 [Originally published in English under the title The Fall of Yugoslavia: The Third Balkan War].

Michael Ignatieff, Blood and Belonging: Journeys into the new Nationalism, Toronto, 1993.

Jaskułowski, Krzysztof. Nacjonalizm bez narodów: Nacjonalizm w koncepcjach anglosaskich nauk społecznych [Nationalism Without Nations: Nationalism in the Concepts of Anglo-Saxon Social Sciences], Wrocław, 2009.

Kamberović, Husnija. Historiografja u Bosni i Hercegovini u službi politike [Historiography in Bosnia and Herzegovina in the Service of Politics], Zagreb, 2012.

Koch, Magdalena, “'My' i 'Oni', 'Swój', i 'Obcy': Bałkany XX wieku z perspektywy kolonialnej" ['“We' and 'They', 'His', and 'Alien': Balkans of the 20th Century from a Colonial Perspective”'], Porównania 6 (2009): 75-93.

Koseski, Adam. "Bałkańskie konflikty etniczne w latach dziewięćdziesiątych XX wieku” ["Balkan ethnic conflicts in the 1990s"], Rocznik Nauk Politycznych (2000), No. 1 (2)

Koseski, Adam. "Bałkańskie konflikty etniczne na przełomie XX i XXI stulecia" [,Balkan Ethnic Conflicts at the Turn of the 20th and 21st Centuries'], in: Bałkany etnokulturowe podłoże konfliktów, W. Konarski, A. Koseski (eds.), Pułtusk, 2006, pp. 93-120.

Krysieniel, Krzysztof. W cieniu Dayton: Bośnia i Hercegowina między etnokracja i demokracja konsocjonalna [In the Shadow of Dayton: Bosnia and Herzegovina between Ethnocracy and Consocational Democracy], Warsaw, 2012.

Mahmutćehajić, Rusmir, "Bošnjaci i/ili/ Muslimani” ["Bosniaks and/or/ Muslims"], in: Atif Purivatra, Mustafa Imamović, Rusmir Mahmutćehajić, Muslimani i bošnjaštvo, Sarajevo, 1991. 
Meinecke, Friedrich. Weltbürgertum und Nationalstaat: Studien zur Genesis des deutschen Nationalstaates [World Bourgeoisie and Nation State: Studies on the Genesis of the German Nation State] (Munich-Berlin, 1928)

Moroz-Grzelak, Lilla. "The Specificity of the Bosnia and Herzegovina Borderland and the Issue of Bosnian identity", Sprawy Narodowościowe (2007), No. 31, 2007: 307-314.

Redžić, Enver, Sto godina muslimanske politike: U tezama i kontraverzama istorijske nauke: Geneza ideje bosanske, bošnjačke nacije [One Hundred Years of Muslim Politics: In The Theses and Controversies of Historical Science: The Genesis of the Idea of the Bosnian, Bosniak Nation], Sarajevo, 2000.

Robertson, David. Stownik polityki, Warsaw, 2009 [Originally published in English under the title The Routledge Dictionary of Politics].

Saltaga, Fuad. Muslimanska nacija u Jugoslaviji [Muslim Nation in Yugoslavia], Sarajevo, 1991.

Sarač-Rujanac, Dženita. Odnos vjerskog i nacionalnog u identitetu Bošnjaka od 1980. do 1990. godine [The Relation of Religious and National in the Identity of Bosniaks from 1980 to 1990], Sarajevo, 2012.

Smith, Anthony D. Nacjonalizm (Warsaw, 2007) [Originally published in English under the title Nationalism: Theory, Ideology, History].

Smith, Anthony D. Etniczne źródła narodów [Originally published in English under the title The Ethnic Origins of Nations], Kraków, 2009.

Šabotić, Izet, "Nacionalno pitanje Bošnjaka - Muslimana u projekcijama Komunističke Partije/Saveza Komunista Jugoslavije" ["The National Question of Bosniaks - Muslims in the Projections of the Communist Party / League of Communists of Yugoslavia"], in: Identitet Bosne i Hercegovine kroz historiju: Zbornik Radova, Husnija Kamberović (ed.), volume 2, Sarajevo, 2011, pp. 127154.

Šindler Džon R. [Schindler, John R.], Nesveti terror: Bosna, Al Kaida i uspon globalnog dżihada, Belgrade, 2009 [Originally published in English under the title Unholy Terror: Bosnia, Al-Qa'ida, and the Rise of Global Jihad].

Trifunović, Darko. Islamic Terrorism and Al Qaeda in the Balkans: Testimony of Former Al Qaeda Lieutenant, Alexandria, 2014.

Marek Waldenberg, Kwestie narodowe w Europie Środkowo-Wschodniej: Dzieje, Idee [National Issues in Central and Eastern Europe: History, Ideas], Warsaw, 1992.

Wituch, Tomasz, "Bałkany - szkic definicji" ["Balkans - definition sketch”], Dzieje Najnowsze XXX (1998), No. 2: 135-143. 
Wojciechowski, Sebastian. Nacjonalizm w Europie Środkowo-Wschodniej [Nationalism in Central and Eastern Europe], Wrocław, 1999.

Zalewski, Krzysztof M. Naród, religia, rasa. Muzułmańskie ideologie i ruchy narodowe pogranicza w Południowo-Wschodniej Europie: Przykład Sandżaka nowopazarskiego w XX wieku [Nation, Religion, Race: Muslim Ideologies and National Movements of the Borderland in Southeastern Europe: An example of the Sanjak of Novi Pazar in the $20^{\text {th }}$ Century], Warsaw, 2010. 